\title{
КОНОТАТИВНА ЕКВІВАЛЕНТНІСТЬ У ПЕРЕКЛАДІ
}

Амеліна С. М. Конотативна еквівалентність у перекладі.

У статті розглядається питання конотативної еквівалентності в перекладі. Констатовано, що конотації пов'язані зі стилістичними особливостями мовних засобів. Визначено, що досягнення конотативної еквівалентності перекладу може відбуватися шляхом використання різних прийомів (транскрипція та транслітерація, калькування, описовий переклад, приблизний переклад, генералізація).

Ключові слова: конотація, конотативна еквівалентність, стиль, прийоми перекладу.

Амелина С. Н. Коннотативная эквивалентность в переводе.

В статье рассматривается вопрос коннотативной эквивалентности в переводе. Констатировано, что коннотации связаны со стилистическими особенностями языковых средств. Определено, что достижение коннотативной эквивалентности перевода может происходить путем использования различных приёмов (транскрипция и транслитерация, калькирование, описательный перевод, примерный перевод, генерализация).

Ключевые слова: коннотация, коннотативная эквивалентность, стиль, приёмы перевода.

Amelina S. M. Connotative Equivalence in Translation.

The article deals with connotative equivalence in translation. It is stated that the connotations are associated with the stylistic features of the language means. It is determined that the achievement of connotative equivalence in translation equivalence may occur through the use of various techniques (transcription and transliteration, loan translation, descriptive translation, rough translation, generalization).

Key words: connotation, connotative equivalence, style, techniques of translation.

У зв’язку з інтенсифікацією міжнародних контактів проблема якості перекладу набуває дедалі більшої актуальності. Діяльність перекладача сприяє досягненню порозуміння між представниками різних культур і мовних спільнот. Складність полягає в тому, що для перекладу деяких мовних феноменів не існує відповідників, які разом 3 передачею специфічної інформації відображали б національний колорит, мали б ті самі конотації емоційного, смислового та стилістичного характеру, що супроводжують їх в оригінальному тексті. При цьому постає питання еквівалентності перекладу - денотативної, конотативної, нормативної, прагматичної.

Мета статті - розглянути особливості конотативної еквівалентності 
в перекладі.

Різні аспекти конотації досліджувались вітчизняними і зарубіжними вченими: визначення конотації (Ю. Апресян), образна конотація (Е. Бузунова), конотація як компонент значення (С. Винниченко), мовні засоби соціальної конотації (А. Дяченко), конотація у сучасній німецькій мові (Н. Оніщенко). Однак, питання конотативної еквівалентності як однієї із проблем перекладу потребує окремого вивчення.

Денотативне значення належить до постійного, контекстнонезалежного основного значення мовного вираження певного поняття. Мовознавці наголошують на тому, що крім денотативного значення, яке $є$ ядром лексичного значення й обмежує поняття, важливою є й інша складова - конотативне значення, яке вносить на додаток до функції іменування оцінювальний, емоційний, стилістичний, асоціативний компоненти. Тобто конотативне значення містить ознаки, які передають ставлення мовця до сказаного - оцінку (позитивну чи негативну) i почуття. Основні складові значення представлені на рис. 1.

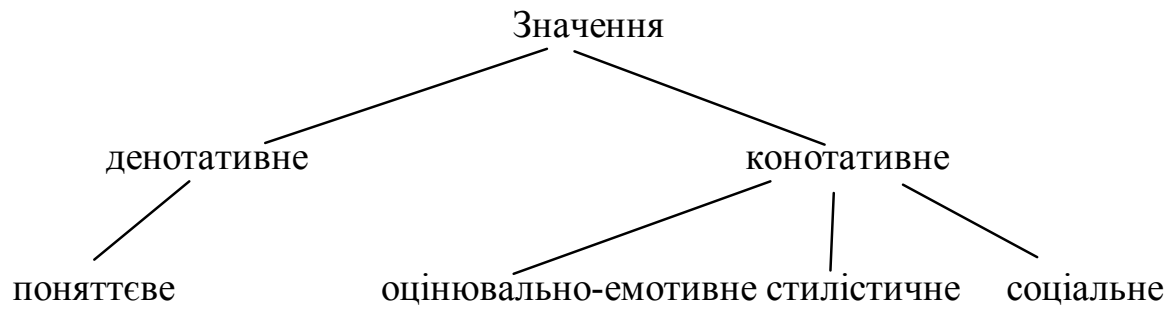

Рис. 1. Складові лексичного значення

При розгляді феномену конотації більшість дослідників спирається на дефініцію, запропоновану Ю. Апресяном: «...конотаціями лексеми ми будемо називати несуттєві, але стійкі ознаки вираженого нею поняття, які втілюють прийняту в даному мовному колективі оцінку відповідного предмета чи факту дійсності. Вони не входять безпосередньо до лексичного значення слова i не $\epsilon$ наслідками або висновками 3 нього» [1, с. 159]. Спільним у поглядах дослідників при тлумаченні поняття конотації $є$ його протиставлення поняттю денотації.

(C) С. М. Амеліна, 2014. 
Під денотацією розуміють постійне основне значення, незалежне від контексту і ситуації, тобто це зв'язок між мовним об'єктом (словом) і позамовним об’єктом (так званим денотатом).

Натомість конотація - це:

- індивідуальний (емоційний), стилістичний та інші компоненти значення, які накладаються на основне значення;

- експресивне значення: стилізована оцінка фактів мовцем;

- соціальне значення: компонент значення, який відображає соціальні відносини (часто говорить між мовцем і слухачем).

Отже, дослідники протиставляють денотацію i конотацію за кількома основними характеристиками, які ми узагальнили в Таблиці 1.

Таблиця 1

Порівняння основних ознак денотації і конотації

\begin{tabular}{|l|l|l|}
\hline \multicolumn{1}{|c|}{ Денотація } & \multicolumn{1}{|c|}{ Конотація } \\
\cline { 2 - 3 } & \multicolumn{1}{|c|}{ Основне значення } & Другорядне значення \\
\hline Об'єктивність & Суб'єктивність \\
\hline Експліцитність & Імпліцитність \\
\hline Стійкість & Варіативність \\
\hline Незалежність від контексту & Контекстна зумовленість \\
\hline Незалежність від культурно-соціальних умов & Культурно-соціальна залежність \\
\hline Логічність & Парадоксальність \\
\hline Загальновживаність & Регіональність \\
\hline Традиційність & Індивідуалізація \\
\hline Концептуальність & Асоціативність \\
\hline Відкритість & Завуальованість \\
\hline Стилістична нейтральність & Стилістична забарвленість \\
\hline Безоцінність & Оцінювання \\
\hline Раціональність & Емоційність \\
\hline Суттєість & Несуттєвість \\
\hline
\end{tabular}

Більшість із наявних визначень конотації або іiі окремих типів вказують на такі сутнісні ознаки:

а) додатковість до денотативного аспекта значення;

б) вторинність щодо денотації;

в) інтерпретативний характер, інтерпретація денотативного або квазіденотатівного (образно мотивованого) аспектів значення в категоріях культури;

г) гетерогенність і гетерофункціональність складових іiі компонентів при вираженні оцінковості, емоційності, експресивності;

д) імпліцитність як спосіб вираження; 
е) стратифікаційна нелокалізованість (наявність конотативної потенції мовних одиниць);

ж) дискурсивний характер комунікативної значущості;

3) варіативність під впливом соціокультурних факторів на саму мову і їі використання;

i) динамізм, зумовлений змінами в межах лінгвокультурної спільноти або умовами конкретної комунікативної ситуації [2, с. 32].

Конотативні значення поділяються дослідниками на два типи: позитивно-конотативні i негативно-конотативні. Позитивною конотацією $є$ розширення значення в позитивному сенсі, а негативною - у негативному сенсі.

Слід зазначити, що незважаючи на другорядність значення конотації, вона може містити і сутнісну інформацію. Зокрема, це стосується синонімів, які позначають один денотат, але використовуються в науково-технічній і побутовій сфері. Наприклад, der Boden - грунт i підлога. Аналогічним прикладом може бути використання регіональних (діалектальних) синонімів: Marille (австрійська німецька) й Aprikose (німецька).

Отже, при цьому постає проблема забезпечення конотативної еквівалентності при перекладі, адже конотативні значення актуалізуються тільки в певному контексті, тобто переважно $\epsilon$ нестійкими. Тому більшість дослідників вказує на їх вторинність, мовну нерелевантність, часто зводячи їх до індивідуальних асоціацій.

Дійсно, конотації більшою мірою залежать від мовця або певної групи мовців, яка їх використовує. Однак, низка соціальних i психосоматичних досліджень, проведених зарубіжними вченими, засвідчила, що деякі конотації поділяє більшість носіїв мови певної спільноти.

На нашу думку, незважаючи на те, що з позиції лексикографії, конотації $є$ другорядними і їх не можна однозначно експлікувати, вони створюють певний образ, який без цього був би не зовсім точним або неповним. «Конотації слів, які, здавалося б, повністю можна перекласти, здебільшого ніде не зафіксовані, насамперед через їх залежність від контексту, і це вимагає багато знань про реальність етнічних груп вихідної мови, іншими словами, високої культурної компетентності, перш ніж вдаватися до пошуку найбільш адекватного перекладацького рішення. Наш самовар, наприклад, це більше, ніж російський чайник, це слово також означає затишність старих хороших 
днів; і винний льох це більше, ніж винний льох, він разом зі своїми піснями $є$ втіленням особливої віденської привітності. Відповідна конотація актуалізується тільки у контексті» [10, с. 289-290].

У результаті спостереження над інтерпретацією художніх текстів Р. Токарськи запропонував модель семантичної структури слова 3 трьома відокремленими колами. У центрі міститься значеннєве ядро лексичне значення. Його створює зміст, найтісніше зв'язаний з формою слова, який найпростішим чином значеннєво ідентифікує лексему. Навколо ядра поширюється зона факультативних рис, настільки виразних і стійких у свідомості звичайного носія мови, що їх можна виявити через процедури, які звертаються до явищ мовної системи. До традиційно вживаного для позначення цих рис терміну «конотація» він додає означення, яке, на думку дослідника, уточнює їх природу: системна конотація. Ще на більшій відстані від центру виступає багата i практично відкрита зона конотацій, які не можна верифікувати шляхом формальних процедур, які звертаються до явищ системних, але мовно важливих, бо необхідних для бачення конкретного тексту, текстів конкретного автора, літературної групи тощо [11].

На основі аналізу перекладу художніх творів, Т. Левандовскі вважає, що конотація як компонент значення слова, будучи другорядним значенням, що супроводжує основне значення, накладається на нього, надає йому емоційності, оцінності, тісно пов'язане зі ставленням автора, а саме його прагматичним вибором 3 метою бажаного впливу на читача, адже вона не тільки афективно й емоційно забарвлює слово чи вислів, але й може бути оцінною. 3 іншого боку, щодо денотативного значення йдеться про ядро значення слова, яке сприймається когнітивно і не залежить від конкретної ситуації. 3 позиції дослідника, ця дихотомія не завжди може бути достатнім критерієм при описі значення слова. Слід зважати на проблематичність розмежування семантики i прагматики, що не завжди є можливим. Однак, оскільки переклад здійснюється завжди в певному контексті, то можна вважати, що при цьому обов'язково буде враховано прагматичний елемент [9].

Конотації здебільшого пов'язані зі стилістичними особливостями мовних засобів. На думку С. Тер-Мінасової, поява різних стилістичних конотацій у словах різних мов зумовлена різними культурними уявленнями різних народів про ті предмети і явища реальності, які позначені «еквівалентними» словами цих мов [5, с. 159]. Тому 
дослідниця акцентує, що мовна еквівалентність - це міф, який розсипається, якщо взяти до уваги такі фактори, як обсяг семантики, лексична сполучуваність, стилістичні конотації, культурологічний аспект еквівалентності слів різних мов.

Певною допомогою при перекладі задля того, аби досягти конотативної еквівалентності, може стати стилістичне маркування у словниках. Так, Duden вказує на такі стильові особливості і варіанти: високий (зокрема й поетичний) стиль, мовно-академічний, нормативний, розмовно-мовний, грубий, вульгарний.

Тому перекладач, розглядаючи синонімічні ряди й обираючи варіанти, що мають задовольнити вимоги еквівалентності / адекватності перекладу, повинен аналізувати стилістичне забарвлення лексики. Як правило, периферійна лексика семантичних полів $\epsilon$ стилістично забарвленою. Наприклад:

- Іменники

Auto - Karre - Klapperkiste - Schlitten;

Ehefrau - Gattin - Gemahlin;

Fahrkarte - Billett - Fahrausweis - Ticket;

Fahrrad - Drahtesel;

Frau - Dame - Weib;

Gefängnis - Knast - schwedische Gardinen - Starfvollzugsanstalt ;

Gesicht - Angesicht - Antlitz - Fratze;

Kleidung- Klamotten - Sachen;

Kopf -Birne - Haupt - Rübe;

Pferd - Gaul - Ross;

Zimmer - Gemach - Kammer - Stube.

- Прикметники

hässlich - entartet - monströs;

lieb - liebenswürdig - zuckersüss;

schnell - eilig - flink - hastig - rasch;

- Дієслова

bekommen - erhalten - kriegen;

essen - fressen - speisen;

laufen - eilen - rennen;

sprechen - klatschen - plaudern - schwatzen;

verstehen - begreifen - kapieren.

Переклад культурно-конотованої лексики може здійснюватися різними способами, зокрема, такими: транслітерація і транскрипція С С. М. Амеліна, 2014. 
(нім. Bundestag - бундестаг, Bundesrat - бундесрат, Bundeswehr бундесвер, Gastarbeiter - гастарбайтер); калькування (нім. Bundesland федеральна земля); описовий спосіб (нім. Asylbewerber - особи, які претендують на притулок, Teilzeit-Job - робота 3 неповною зайнятістю, Vollzeit-Job - робота 3 повною зайнятістю); генералізація (нім. Fachwerkhaus - будинок); приблизний переклад.

Стосовно конотацій фразеологізмів, дослідники підкреслюють, що їм властиві непередбачувані ознаки. Вони нестійкі, їх конотативна характеристика у словниках $\epsilon$ тільки пропозицією. Кожен фразеологізм може актуалізуватися в конкретному контексті зовсім інакше, ніж це зафіксовано в нормативних словниках.

Особливо складно обрати прийом передачі фразеологічної одиниці 3 власним іменем, вибір якого залежить, на думку О. Шаповалової, від функції цієї фразеологічної одиниці, від функції іiі національнокультурної конотації, від інтенції автора, від загальної тональності тексту, від аудиторії, для якої призначений переклад. Зокрема, при передачі фразеологічної одиниці 3 іменем власним часто доводиться жертвувати національно-культурною конотацією, щоб точно передати інформацію, яку містить фразеологізм. Якщо не підходить жоден із прийомів передачі фразеологічної одиниці, перекладач змушений вдаватися до нефразеологічного перекладу [7, с. 32].

Повної еквівалентності можна досягти, застосовуючи перекладацький прийом субституції. Найбільшу частину таких фразеологізмів складають ті, для яких не є характерними емоційна i стилістична забарвленість. Наприклад: Ferner Osten - Далекий Схід, kalter Krieg - холодна війна. Однак субституція може застосовуватися й у тому разі, коли образність фразеологізмів у вихідній і цільовій мовах співпадає або співвідноситься, напр.: wie ein Blitz aus heiterem Himmel - як грім з ясного неба, stolz wie ein Pfau - пихатий як павич.

Часткова еквівалентність досягається при перекладі ідіом, повністю еквівалентних за їх денотативним значенням, але різних за конотативними відтінками, зумовлених соціальними, культурними або історичними причинами. Наприклад: gelb vor Neid - позеленіти від заздрощів, aus einer Mücke einen Elefanten machen - робити з мухи слона.

Л. Латишев визначає лексичні трансформації як відхилення від словникових відповідностей [3]. У значенні слова в різних мовах часто виділяються різні ознаки одного й того ж явища чи поняття, де відображено бачення світу, властиве цій мові, точніше, носіям цієї 
мови, що неминуче створює труднощі при перекладі.

Параметрами оцінки способів відтворення (перекладу), за В. Куцем [8], є: інформаційна насиченість способу; зрозумілість еквівалентів для реципієнтів цільової мови; прозорість культури вихідної мови; доцільність.

Іншою важливою проблемою, яка постає перед перекладачем, $є$ питання щодо вибору мовних одиниць цільової мови в перекладах, пов'язане 3 можливим мимовільним вживанням конотацій. Варто проаналізувати переклад як продукт, який може містити неоднозначне тлумачення обраних мовних одиниць у контексті. Адже тоді переклад не досягне мети, а наслідком буде неправильне розуміння, неповна інформація, дезорієнтація користувача, для якого призначений цей переклад. Особливої уваги вимагає використання стереотипів і кліше. Тому при виборі слів перекладач повинен обов'язково враховувати, що багато термінів мають, крім основного, ще й додаткові значення, які автор перекладу може ненавмисно «включити» у свій переклад.

Слід зазначити також, що значні труднощі в роботі перекладача можуть зумовити конотації, пов'язані зі стереотипним сприйняттям власних імен. Ці конотації є дуже різноманітними, поняття конотації тут вживається в широкому сенсі. Хоч деякі конотативні значення укорінилися в багатьох мовах і не викликають сумнівів у правильності їх сприйняття (напр.: Der junge General ist ein Napoleon), водночас пошуки еквівалентів для адекватного сприйняття користувачем-представником іншої культурної і мовної спільноти є здебільшого проблематичним.

Отже, вибір перекладачем стратегії визначається не тільки типом тексту i реципієнтом, але й співвідношенням, тобто ступенем близькості або віддаленості між культурами вихідної і цільової мов.

Одну із проблем при цьому можуть становити реалії як елементи повсякденного життя, історії, культури, політики однієї національної чи культурної спільноти, аналогів яких немає у інших народів чи в інших країнах. Реалії є носіями ідентичності національної культури або етнічної належності. Для того, щоб реципієнту були зрозумілими реалії, відображені у вихідній мові, потрібні певні трансформації, контекстуальні пояснення тощо. Реалії пов'язані 3 конотаціями, які реалізуються в контексті. Так, ein Mass означає не тільки міру, а й посуд для пива місткістю 1 л, що є типовим для всесвітньовідомого німецького пивного фестивалю Октоберфест, який щорічно відбувається в Мюнхені. Оскільки конотації актуалізуються в контексті, то труднощі перекладача 
часто більшої мірою викликані не перекладом реалій, а саме необхідністю адекватної передачі конотацій.

До того ж у нинішній ситуації мультилінгвальності й глобалізаційних процесів, які прискорюють взаємопроникнення і взаємозбагачення мов, коннотації часто пов'язані із залежністю від сприйняття і знання європейських культур та мов. Зазначені чинники впливають на афективний i конотативний вимір мовних систем. Окремим питанням при цьому $\epsilon$ політкоректність, актуальність дотримання якої особливо загострилася останнім часом. Так, перші три одиниці поданого ряду мають негативне конотативне маркування, а остання є нейтральною: Neger - Schwarze - Farbige - Afro-Amerikaner.

Висновки та перспективи подальших досліджень. У процесі своєї діяльності перекладач зіштовхується 3 проблемою вибору прийому передачі не тільки денотативного, але й конотативного значення. Можливість адекватного відтворення конотативного значення іншою мовою $\epsilon$ обмеженою. Досягнення конотативної еквівалентності перекладу може відбуватися шляхом використання різних прийомів (транскрипція та транслітерація, калькування, описовий переклад, приблизний переклад, генералізація тощо).

Подальші наукові дослідження можуть бути пов'язані 3 вивченням особливостей різних прийомів перекладу задля досягнення конотативної еквівалентності.

\section{Література}

1. Апресян Ю. Д. Интегральное описание языка и системная лексикография / Ю. Д. Апресян. - М. : Школа «Языки руссской культуры», 1995. - 767 с.

2. Быкова О. И. Лингвокультурологический подход к исследованию этноконнотации / О. И. Быкова // Вестник ВГУ. Серия «Лингвистика и межкультурная коммуникация. -2001 . - № 2. - С.32-38.

3. Латышев Л. К. Технология перевода / Л. К. Латышев. - М. : Академия, 2007. $320 \mathrm{c}$.

4. Ревзина О. Г. О понятии коннотации / О. Г. Ревзина // Языковая система и её развитие во времени и пространстве. - М. : Изд-во МГУ, 2001. - С. 436-446.

5. Тер-Минасова С. Г. Язык и межкультурная коммуникация / С. Г. Тер-Минасова. - М. : Слово/Slovo, 2000. $-624 \mathrm{c.}$

6. Умерова М. В. Полноценность и адекватность перевода в современном переводоведении / М. В. Умерова // Университетское переводоведение: материалы VIII юбилейной международной научной конф-ции по переводоведению. - СПб : Филологический ф-т СПбГУ, 2007. - № 8. - С. 468-474.

7. Шаповалова Е. О. К вопросу об эквивалентной передаче фразеологизмов с именами собственными / Е. О. Шаповалова // Вестник Челябинского 
государственного университета. - 2012. - № 20 (274). - С. 151-153.

8. KutzW. Was heißt Babyklappe auf Spanisch? Entsprechungslücken als dolmetschspezifischer Problemfall / W. Kutz // Lebende Sprachen. - 2009. N 3. - S. 98-112.

9. Lewandowski T. Linguistisches Wörterbuch / T. Lewandowski. - B. 1-3. Heidelberg, Wiesbaden : Quelle und Meyer. - 376 S.

10. Markstein E. Realia / E. Markstein / M. Snell-Hornby (Hrsg.) / Handbuch Translation. - Tübingen : Stauffenburg, 1999. - S. 288-291.

11. Tokarski R. Znaczenie słowa i jego modyfikacje w tekście / R. Tokarski / Konotacja jako składnik treści słowa. - Lublin, 1987. - S. 35-54.

12. Vandermeeren S. Semantik deutscher Substantivkomposita mit Verwandtschaftsbezeichnungen / S. Vandermeeren // Deutsche Sprache. - 1998. - N 26/3. - S. 240 -255.

13. Wiegand H. E. Semantik, Pragmatik und Wörterbuchform in einsprachigen Wörterbüchern / H. E. Wiegard. - Zeitschrift für Germanistische Linguistik. Deutsche Sprache in Gegenwart und Geschichte. - 2010. - N. 38. - S. 405-441.

14. Variantenwörterbuch des Deutschen : Die Standardsprache in Österreich, der Schweiz und Deutschland sowie in Liechtenstein, Luxemburg, Ostbelgien und Südtirol / [hrsg. von Ulrich Ammon]. - Berlin, 2004. - 815 S.

15. Wörterbuch Richtiges und gutes Deutsch : Das Wörterbuch der sprachlichen Zweifelsfälle / [hrsg. vom Wissenschaftlichen Rat der Dudenredaktion unter Mitwirkung von Peter Eisenberg und Jan Georg Schneider]. - Mannheim, 2011. - 927 S.

Стаття надійшла до редакиї̈ 24.09.2014 p. 